\title{
Menjaga Cagar Budaya di Tegal
}

\author{
Fathurozi \\ Warga Tegal, Ketua Komunitas Mahasiswa Kreatif (KMK) \\ Fakultas Dakwah IAIN Walisongo
}

\begin{abstract}
SUATU kota mempunyai identitas khas daerah. Biasanya masyarakat yang berkunjung akan lebih mudah mengenang ikon kota tersebut. Selama ini, Tegal terkenal dengan sebutan kota industri, namun masyarakat belum banyak yang tahu, bahwa daerah itu menyimpan benda peninggalan sejarah berumur 50 -an tahun.
\end{abstract}

Pesatnya pertumbuhan ekonomi di wilayah itu ditandai dengan berdirinya pusat perbelajaan modern, seperti Mal Sri Ratu Pasifik, Rita Swalayan, di jalur menuju Jakarta dan arah selatan (Purwokerto) terdapat mal Dedi Jaya dan supermarket-supermarket berskala medium.

Tiap sudut kota terdapat toko atau supermarket medium modern, bahkan sampai masuk kecamatan. Pasar ini, banyak dilirik masyarakat karena tempatnya bersih nyaman, pelayanan yang memuaskan. Minat masyarakat berbelanja di pasar itu cukup tinggi, pasar tradisional direnovasi mirip pasar modern. Semata-mata memberikan fasilitas yang lebih.

Namun, pembangunan pusat modern ini, kurang memperhatikan benda peninggalan sejarah atau benda cagar budaya (BCB). Gedung ini, tergerus oleh kekejaman zaman. semisal rumah tua milik RA Kardinah, adik kandung RA Kartini, berubah menjadi Mal Dedy Jaya, Keraton Kaloran berubah menjadi halaman parkir sebuah mal, Gedung Kepatihan menjelma menjadi Pasar Pagi, gardu listrik di tepi alun-alun "lenyap" dan lampu gantung pengetur arus lalu lintas di perempatan Tumpuk "hilang tak berbekas".

Gedung-gedung yang masih berdiri yakni markas Kutil, tokoh revolusi tiga daerah berubah jadi kantor bank swasta, demikian gedung transportasi kereta api (KA) berlantai tiga yang dulu sebagai kantor biro Semarang-Cheribon Stoomtram Matschappij (SCS) zaman kolonial Belanda menjadi sekretariat PTS. Konon bangunan ini, termegah setelah bangunan Lawang Sewu di Semarang. Di dalam gedung terdapat pernak pernik yang memiliki estetika tinggi. Sekilas gedung itu begitu indah, jika dilihat dari dekat cat tembok terkelupas dan di lantai atas dipenuhi sarang walet, menyebarkan bau kurang sedap.

Di Tegal ada sedikitnya ada 100 BCB. Sebagian kondisinya terbengkalai tak bertuan, dalam bahasa Jawa disebut gedung suwung (kosong), pemilik meninggalkan begitu saja tanpa ada perawatan, bahkan hampir 50 persen dalam di ambang kerusakan. Padahal gedung itu simbol artefak perjalanan Tegal.

Gedung tersebut, banyak dimiliki instansi swasta dan perseorangan dari pembagian warisan. Bangunan itu dijual, hasilnya dibagi rata ke anggota waris, mungkin saja 
mereka tergiur nilai jual yang tinggi. Pembeli menyulap cagar budaya menjadi mal-mal modern sekelas di kota metropolitan.

\section{Tegal Keminclong}

Kelihatannya Pemerintah Kota Tegal ingin menjadikan daerah itu sejajar dengan Ibu kota. Terbukti dengan slogan Tegal Keminclong Moncer Kotane (Tegal Bercahaya Meriah Kotanya). Ketika malam sepanjang jalan kota dihiasi kelip-kelip lampu warnawarni dan tempat hiburan yakni diskotek, kafe ikut memeriahkan denyut kota. Bahkan beberapa hotel berbintang dibangun di jantung kota.

Menuju kota modern, pembangunan infrastruktur terus dibenahi, dan pelaku bisnis raksasa bergerilya mencari tempat strategis untuk membangun usahanya. Hanya saja pebisnis itu kurang mempertimbangkan nilai BCB. Bagi mereka (pebisnis) yang penting mendatangkan keuntungan.

Pernah suatu ketika, penulis bercakap-cakap dengan beberapa siswa SMA, mengenai letak BCB di Tegal, rata-rata mereka kesulitan menyebutkan tempat itu. Tapi salah satu dari mereka spontan menunjukkan jari ke gedung tua. Dari mana mereka tahu itu cagar budaya? Jawabnya, karena bentuknya kuno, unik, dan berbeda dari gedung-gedung di sampingnya.

Ironis sekali, seorang terpelajar kurang mengetahui sejarah kotanya sendiri, sebaliknya mereka mengetahui tahun berdirinya mal-mal. Seharusnya pelajar lebih tahu mengenai BCB karena sehari-hari beraktivitas di kota itu..

Melihat kondisi BCB semakin mengkhawatirkan, tahun 1998, pejabat Kantor Museum dan Purbakala Jawa Tengah mengirim surat imbauan penyelamatan BCB di Kota Tegal. Namun pemerintah daerah kurang merespons dengan dalih masih kesulitan menginventarisasi mana saja yang termasuk benda sejarah dan bukan cagar budaya, selain faktor keterbatasan tenaga arkeolog.

Terkadang kita tidak bisa menyalahkan pemilik menjual BCB itu. Ketidaktahuan mereka pada bangunan warisan orang tua yang ternyata mengandung nilai sejarah, sehingga sekarang pengusuran BCB tak terbendung.

Bila merujuk keputusan Menteri Pendidikan dan Kebudayaan Nomor 87/P/ Tahun 1993 Pasal 5 Ayat 2 disebutkan bahwa kepemilikan, penguasaan, pengalihan hak dan pemindahan tempat benda cagar budaya, harus didaftarkan ke instansi berwenang. 